\title{
Education for Sustainable Development through Dissemination of Good Cleaner Production Practices: University - Industry Collaboration toward Sustainable Agroindustry (A case on Pondoh Snake Fruit based SME)
}

\author{
Anggoro Cahyo Sukartiko*, Nafis Khuriyati, Wagiman, Wahyu Supartono, and \\ Muhammad Prasetya Kurniawan
}

Department of Agroindustrial Technology, Faculty of Agricultural Technology Universitas Gadjah Mada, Jl. Flora No.1 Bulaksumur 55281, Indonesia.

Email: cahyos@ugm.ac.id*

\begin{abstract}
Higher education plays an important role in the implementation of Education for Sustainable Development (ESD). Together with industry, the collaboration can provide a wider multiplier effect. Among others, agro-industry is one of sector that provides vast employment opportunities both on- and off-farms, which potentially improve welfare of human involved. However, its activities in effort to meet the needs of rapid increase of world's population faced with scarcity problems, sometimes merely focus on economic sustainability. Therefore, disseminating good cleaner production practices, which emphasizes the reduction or removal of environmental contamination at the source (front of pipe concept) can be done to educate agro-industrial actors to implement sustainable development. Collaboration model between university and agro-industry in Education for Sustainable Development of Agroindustry is discussed in the paper.
\end{abstract}

Keywords: cleaner production, sustainable agro-industry, university - industry collaboration

\section{INTRODUCTION}

Higher education plays an important role in the implementation of Education for Sustainable Development (ESD). Their role is one key aspect in moving the nation toward more sustainably developed future. They can provide information and awareness on the importance of sustainable development, and able to mobilize the masses / community toward a better future. Provision of these information and awareness follows cognitive levels in the Revised Bloom's Taxonomy, in accordance with educational purposes. Together with industry, the collaboration can provide a wider multiplier effect.

Among others, in Indonesia, agroindustry is one of sector that provides vast employment opportunities both on- and offfarms, which potentially improve welfare of human involved. Such agro-industrial activities as producing, processing, handling, packaging, transporting, marketing and distribution of food and agricultural products provide opportunities for the involved people in generating incomes. Therefore, it cannot be denied that agro-industrial activities contribute to economic development and poverty reduction. However, as the growth of world's population is much higher than that of food and agricultural product availability, problem of food and agricultural product scarcity may arise in the future. Such scarcity might be related to lack of its quantity, quality and uneven distribution.

Lack of quantity of food and agricultural products can be attributable to climate change that brings about drought risk, shifting crop cycle, productivity loss, and degradation of water resources as well as soil fertility. Lack of good quality of food and agricultural products might result from poor quality control and management, inappropriate processing technology or handling methods. Uneven distribution might be connected with geographical obstacles among countries, but providing global trade opportunities. In relevant to such issues, sustainable and 
competitive agro-industries should able to cope with food security and food safety problems without exacerbating environmental destruction that already exists today. Sustainable agro-industries ought to be environmentally friendly, safely and be conducted efficiently and effectively for the sake of human welfare.

\section{PROPOSED CONCEPT AND MODEL}

As one unit of education at UGM, Department of of Agro-industrial Technology (DAIT) has an obligation to realize sustainable agroindustry through the provision of human resources that have the competence of ecoagrotechnopreneurship, which is simply defined as the agro-industrialists entrepreneurial, technology-based and environmentally friendly. Achievement of these conditions is done with the implementation of three higher education pillars, namely education pillar (through mandating several sub competencies in each course), research pillar (through the formation of research groups), and dedication to the community through services/ industrial partners.

On the education pillar, one of the course which is mandated to provide sustainability competence is Cleaner Production (CP), which emphasizes the reduction or removal of environmental pollutants at the source with the concept Front of Pipe (FOP). In 1994, UNEP defines Cleaner Production as a strategy of preventive environmental management and integrated that need to be applied continuously in production processes and products, thereby reducing the risk to humans and the environment (Berkel, 1999). Cleaner production can generate profits in the form of a reduction in the production of byproducts (non-product output) or waste, optimization of resource use and improving the efficiency of production (Suprihatin et al, 2004). This concept does not always need activities that are expensive or sophisticated technology but often result in savings potential to improve competitiveness in the market (Rahayu et al, 2010). Based on this concept it is very appropriate when applied to small and medium-scale agro-industries caused by its much smaller investment than the approach End of Pipe (EOP).
On the research pillar, a relevant research group, namely Sustainable Agro-industrial System (SAiS), has been established by TIP management, which cover the concept of Cleaner Production (CP), Life Cycle Assessment (LCA) and Sustainable Agroindustry. The research group study the uses of five techniques, namely: product modification, goodhouse keeping, modification technologies, modification of the product, and on site 3R (reduce, reuse, recycle). Core implementation of the study are to prevent, reduce and/or eliminate the formation of waste or pollutants at the source, throughout the product life cycle and can be achieved by applying a policy of prevention, control clean technology or environmentally friendly technologies, as well as a fundamental change in attitude or behavior of industrial players.

On the community engagement as the third pillar of higher education, the service has been done through rural / industrial partners. Sri Rejeki is one of SMEs that have collaborated with the department since 2013. The SMEs produces snack food and handicraft made from Pondoh Sallaca. In addition to having a business function, the SME has also an educational function, which allow students and other businesses actors to gain experience and learning from the SMEs. Currently, the industry has done a thorough process of the fruit, not only the flesh, but also the seed and skin to minimize waste produced.

In order to disseminate cleaner production concept to realize sustainable agroindustry, a program that actively involve industrial players and students as prospective agro-industrial players in the near future should be prepared (Figure 2). Through the program, they are expected to apply the entire cleaner production steps, from identification of potential waste sources and inefficiency resources to evaluation of cleaner production performance. Implementation of the program, are expected to give a positive impact on environment, economic, and social condition, which lead to realization of sustainable agroindustry.

\section{LEARNING PROCESS}

Implementation of cleaner production in industry started with a review of production 
processes and improvement opportunities. The study was conducted by students who are taking cleaner production course. Students were divided into small groups, each consisting of 5 students. Results of initial studies showed that small industries has begun to apply the concept of cleaner production, but there are still many opportunities to be improved and enhanced for better quality of industrial environments. The average score of environmental risk assessment (ERA) is consider low (Table 1), which require improvement.

Table 1 Average ERA score

\begin{tabular}{|l|c|c|}
\hline Category & Standard & Score \\
\hline \hline EMS & 10 & 6.00 \\
\hline $\begin{array}{l}\text { Emergency } \\
\text { Preparedness }\end{array}$ & 10 & 5.00 \\
\hline Stromwater & 10 & 4.25 \\
\hline Wastewater & 10 & 3.75 \\
\hline Solid waste & 10 & 6.00 \\
\hline Air Emissions & 10 & 3.50 \\
\hline Energy consevation & 10 & 3.50 \\
\hline Water conservation & 10 & 2.15 \\
\hline
\end{tabular}

Based on Table 1, the students proposed improvement alternatives using the concept of cleaner production, as follows:

1. Recycling of used cooking oil

2. Producing bio-briquette made from snake fruit seed waste

3. Producing snake fruit seed made beverage package

4. Redesigning oven process of snake fruit seed

Alternative packaging coffee beans snake fruit (Figure 1) is the best option as it gives a positive value both for the environment and human health. This product also has the economic prospects that can increase added value for the industry.

SMEs application opportunities of cleaner production principle, based on field investigation, include: the utilization of treated wastewater and snake fruit skin waste, layout improvement, and efficient use of energy.

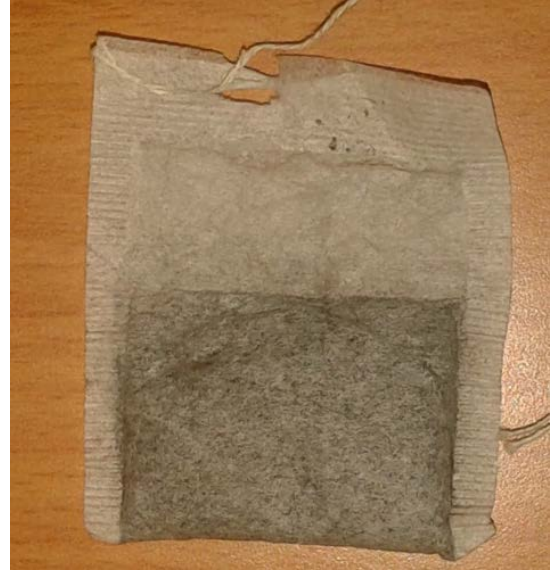

Figure 1 Primary packaging of beverage made from snake fruit seed

\section{LESSON LEARNED AND IDENTIFIED SUCCESS FACTORS}

Selection of industry partners based on its potential, becoming a very important part in determining the success of the activities. Determinants that were learned and identified during the implementation of the activities were as follows:

1. Industry partners should have a good and close relation with the university/ department, where previously they have contributed to the business development of the partners.

2. Industry partners have applied the principles of clean production at some or all of its entire production activities, so that it can be used as an example of learning, both for students, as well as other businesses that want to learn.

3. In addition to the business units that assure the economic sustainability, industrial partners should also has an education unit for disseminating good practices to other parties, such as students, and business actors in the field of agro-industries.

4. The industry partners should has been widely recognized, which allows the introduction of a wider community

5. The owner of industrial partners are often asked to provide material / experience to other business actors, thereby providing a multiplier effect in the dissemination of good practices, including those relating to the principle of net production. 


\section{SUSTAINABLE AGROINDUSTRY}
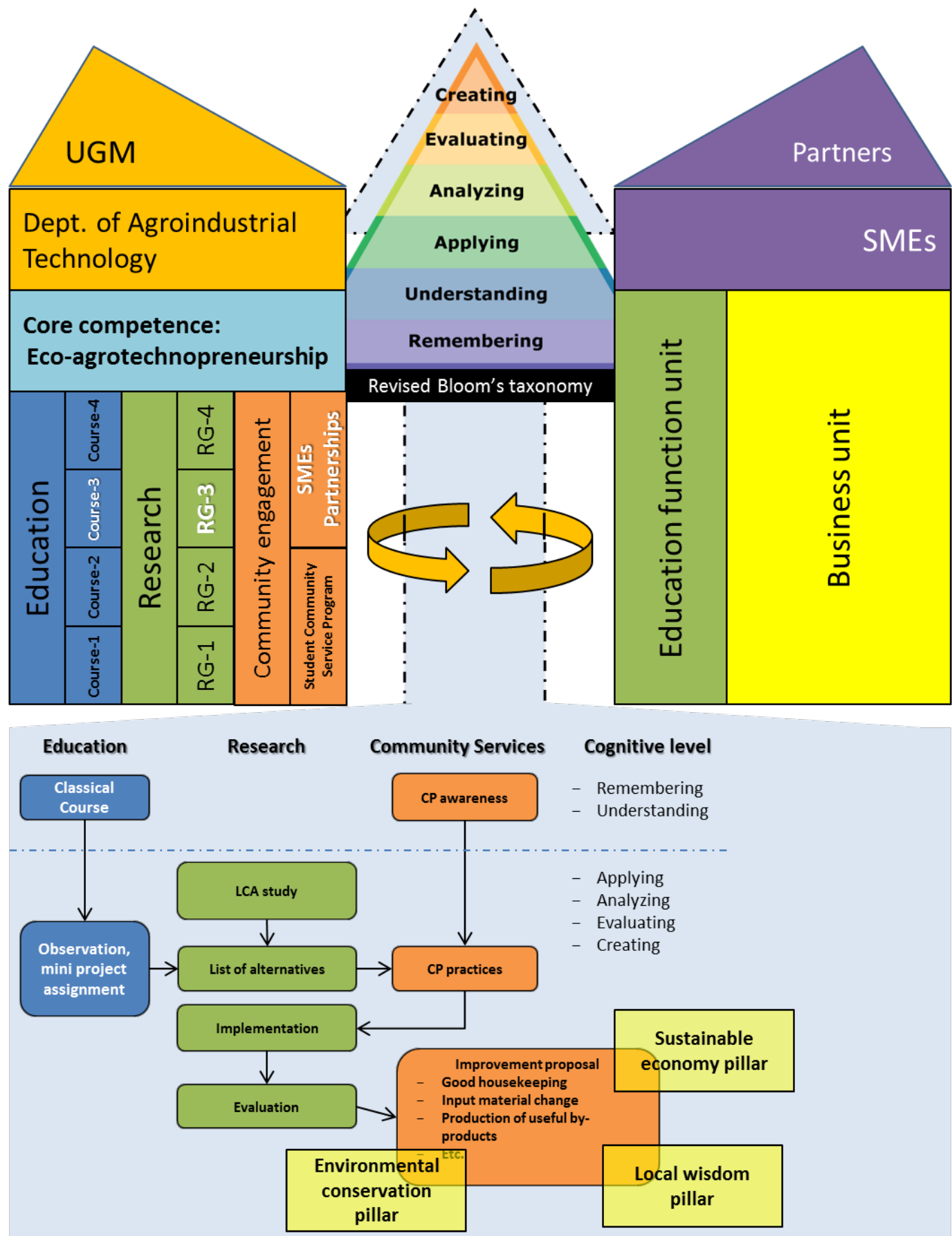

Figure 2 Dissemination Model of Good Cleaner Production Practices: University Industry Collaboration toward Sustainable Agroindustry

\section{CONCLUSSION}

We observed that our industry partners have implemented the concept of cleaner production through the utilization of waste materials during the production process. The concept has been disseminated through education sub-units within our partner's organizational structure, particularly on apprentices (vocational students), thereby providing a multiplier effect on the sustainable development of agro-industry. The involvement of cleaner production course 
learners in proposing improvements contributes to industrial partners.

\section{ACKNOWLEDGEMENT}

We thank Community Service Directorate, Universitas Gadjah Mada for funding the project and Directorate General of Higher Education, Ministry of Science and Higher Education for funding the conference fee and travel and accommodation costs.

\section{REFERENCES}

Berkel, V. R., 1999. Building a Cleaner Word : Cleaner production, its role in Australia, lessons from overseas, and its future applications. John Curtin International Institute.

Rahayu, Setyowati, S., Budiarti, 2010. Penerapan Produksi Bersih pada IKM Batik di Sentra Batik Gamelan, Kabupaten Banjarnegara [Implementation of cleaner production on batik small and medium industry in Batik Center Gamelan, Banjarnegara District]. Jurnal TEKNIS. Vol. 5 No.3: $145-150$

Suprihatin, Romli, M., Ismayana, A. 2004. Penerapan Membran Filtrasi dari Selulosa Asetat dan Chitosan Untuk Produksi Bersih pada Industri Pulp dan Kertas [Application of membrane filtration made from cellulose acetate and chitosan for cleaner production in pulp and paper industry]. Jurnal Tek. Industri Pertanian. Vol. 13 (3): 75-82.

UNEP (United Nation Environment Programme). 2006. Environmental Agreements and Cleaner Production. 